Article

\title{
More Resilient Cities to Face Higher Risks. The Case of Genoa
}

\author{
Francesca Pirlone * $\mathbb{D}$, Ilenia Spadaro $\mathbb{D}$ and Selena Candia \\ Department of Civil, Chemical and Environmental Engineering, University of Genoa, 16145 Genoa, Italy; \\ ilenia.spadaro@unige.it (I.S.); selena.candia@edu.unige.it (S.C.) \\ * Correspondence: francesca.pirlone@unige.it; Tel.: +39-010-335-2820
}

Received: 23 April 2020; Accepted: 10 June 2020; Published: 12 June 2020

\begin{abstract}
This paper analyzes some natural and man-made disasters that happened in recent years, which demonstrate how the resilience of a city does not depend only on the actions carried out by public authorities, but it requires the joint work of all actors that live or work in a city. Resilience represents the ability of an urban system to adapt to an external event and quickly return to normality. In recent years, urban resilience has mainly addressed natural risks, neglecting man-made disaster. Therefore, this study considers the risk issue in relation to the resilience concept within urban planning and policies to achieve sustainability and urban security. Urban resilience has become an important objective for cities, particularly to face climate change. The paper proposes a review of the existing Civil Protection Urban Emergency Plan, as a sector plan to support urban planning at the local level, aimed at building resilience in cities. In particular, the proposed Emergency Plan reduces risk and increases resilience by identifying specific scenarios and actions that every city actor-public authorities, research, enterprises, and citizens-can implement. This proposal contributes to the implementation of the quadruple helix principle, according to which the involvement of these four actors is necessary to achieve a common goal, such as increasing urban resilience. The proposed methodology is then applied to the man-made disasters that have involved the city (such as the flood of 2011 and the collapse of the Morandi Bridge in 2018). Genoa represents a good example to be studied according to the "learning-by-doing" approach to understand how the city has responded, adapting resiliently, to natural and man-made events thanks to the collaboration of all the actors above mentioned. The new scenarios, included in the Urban Emergency Plan, can play a fundamental role, both in the emergency and prevention phase, and can help other cities around the world in planning more resilient cities to face higher risks.
\end{abstract}

Keywords: resilience; territorial security; urban planning; risk mitigation; stakeholder participation

\section{Introduction}

\subsection{Sustainability and Resilience in Urban Planning and Management}

Cities have a key role to play in the fight against climate change [1-3]. They have always been the center of innovation and culture, giving birth to countless ideas and new systems and solutions. Moreover, climate change is affecting urban centers in several critical ways-droughts, heavy rains, water availability, and increased severe heat events; $70 \%$ of cities in the world are already facing the effects of climate change. The urban centers most at risk are the coastal ones, around $90 \%$, which have to deal with rising sea levels, floods, and heavy storms [4]. Over the last decade, many researchers have stressed the importance of new governance tools to improve cities' response to climate change [5-8]. Local authorities need to make the necessary changes to meet future challenges by reducing the vulnerability of people and the urban environment. The role of cities 
is even more important considering that more than half of the world's population lives in urban areas [9-11]. According to the United Nations, by $205068 \%$ of the world population will be living in cities [12]. This means that in the years to come there will be more and more people exposed to risks related to climate change. In order to adapt to future challenges, cities must follow the principles of sustainable development and become increasingly resilient. In the literature, many authors have analyzed the links between the concepts of sustainability and resilience to get the best for society and the environment [13-16].

Since its theorization in the late 1980s and early 1990s, sustainability has become a reference point for the development of communities and urban areas. The widely accepted definition of sustainability is from the Brundtland Commission, which has defined it as "... the development that meets the needs of current generations without compromising the ability of future generations to meet their own needs" [17] (p. 23). In general, sustainability is focused on increasing people's quality of life with respecting three key elements: the economic, environmental, and social well-being, both for the present and the future generations [18-20].

The concept of resilience emerged later. Until the 2000s, resilience was only used in the ecological field, and only later was considered as one of the fundamental approaches to respond and adapt to the increasing natural and human changes on the planet [21]. Resilience focuses on the response of systems (differentiated in environmental, social, and economic systems) to both extreme disturbances (National Research Council, 2012) and persistent stress (Folke, 2016) [22]. Sustainability and resilience are both used to describe a system [23].

There are many similarities between the concepts of sustainability and resilience; for this reason, these terms are often used without clear distinction. Both concepts are used to describe complex systems and issues, but it is important understanding their similarities and differences. In a recent publication, three cases of possible relationships between the two concepts were analyzed. There are studies that considered resilience as a component of sustainability, others in which sustainability was seen as a component of resilience, and finally, there are studies where resilience and sustainability had separate objectives [22].

This paper explores resilience as a component of sustainability. Increasing the resilience of a system makes that system more sustainable, but increasing the sustainability of a system does not necessarily make it more resilient. Sustainability and resilience are key elements to face natural and man-made risks and to guide cities' urban planning choices.

In recent years, the concept of resilience, as a response to environmental, socio-economic, and political uncertainty and risk, has captured the attention of academics and decision-makers in all disciplines, sectors, and scales [24-28]. Urban resilience has become an important objective for cities [29-32]. Urban resilience refers to "the ability of an urban system-and all the ecological and socio-economic networks that make it up on a temporal and spatial scale-to maintain or quickly return to the desired functions in the face of a disturbance, adapting to change" [33] (p. 39). A resilient city reduces or avoids risk situations, establishes procedures to manage emergencies and to restore the damaged system after the event [34]. In the past, urban resilience has mainly addressed natural risks, neglecting man-made disasters. These disasters can include: structure failures, fires, groundwater contamination, transportation accidents, mining accidents, explosions, and acts of terrorism. This paper aims to deepen both types of risks by proposing an approach that integrates the concept of resilience in the decision-making processes of the local urban plans.

\subsection{Adaptation and Mitigation Planning in Europe and in Italy}

Resilience is therefore fundamental for correct management of the territory in case of calamitous events of natural or anthropic origin. In the land-use planning process it is important to involve citizens, and to create plans with risk reduction policies [35].

Urban resilience should be considered both before and after a disaster. In the short-term period people must be resilient to give a quick response. The second time frame is much longer and refers to 
the recovery period, which may change from days to weeks and years [36]. The long-term recovery period is really challenging. Here, resilience and sustainability are linked, as people seek to recover their communities become more resilient (e.g., more adaptable to future adverse events) and also more sustainable (e.g., ensuring future generations can survive and thrive) over the long term [37].

In 2012, 17 sustainable development goals were developed during the meeting Rio +20 . One goal is related to resilience, sustainability and risk-Sustainable Goal 11. This goal states that is necessary to "Make cities and human settlements inclusive, safe, resilient and sustainable". The aim is to "increase ... the number of cities and human settlements adopting and implementing integrated policies and plans towards inclusion, resource efficiency, mitigation and adaptation to climate change, resilience to disasters, develop and implement in line with the forthcoming Hyogo Framework holistic disaster risk management at all levels" [38].

In 2014, the guiding principles for the Hyogo Framework for Action included that "the sustainability of development depends on its ability to prevent new risk creation and the reduction of existing risk" [39] (p. 4). Natural hazard risk management and recovery from natural hazard events are part the sustainability concept [40].

The existing plans that deal with risk, resilience, and sustainability are: Adaptation Plans, where the concept of urban resilience is essential but concerns only hydrogeological risks due to climate change; Municipal Civil Protection Plans, which deepen only the emergency phase and do not consider the prevention; Municipal Land-Use Plans, that consider risk management in different ways. The lack of connections between Emergency and Land Use Plans makes the emergency management less effective to achieve territorial safety [41].

Since the 2000s, the European Union has sought to improve the level of risk management in the member states. However, the EU strategy is mainly focused on natural risk [42]. For example, in 2007, the European Commission defined the Floods Directive 2007/60/EC [43]. This Directive states that "Flood risk management plans should focus on prevention, protection and preparedness.... The elements of flood risk management plans should be periodically reviewed and if necessary updated, taking into account the likely impacts of climate change on the occurrence of floods". The Directive therefore refers to climate change but not to the concept of resilience. In 2013, a specific EU Strategy on Adaptation to Climate Change was designed (Action 7: Making infrastructure more resilient, for creating a climate-resilient region and implementing local climate adaptation plans). "The overall aim of the EU Adaptation Strategy is to contribute to a more climate-resilient Europe. This means enhancing the preparedness and capacity to respond to the impacts of climate change at local, regional, national and EU levels, developing a coherent approach and improving coordination" [44]. In recent years many European cities have implemented adaptation or mitigation plans; in some cases, they have both. Indeed, European cities have responded positively to the Covenant of Mayors initiative and have taken steps to draw up and draft their own Action Plans to achieve the 2020 and 2030 goals. Many of these plans are available on the "Covenant of Mayors for Climate \& Energy platform" opened by the European Union in 2011, with the aim of collecting the initiatives promoted by European cities to address the phenomenon of climate change. In Figures 1 and 2 the Action Plans realized in the in the European cities are reported. The majority of these Action Plans were drawn up in two EU countries: Italy (3184) and Spain (1520) [45]. 


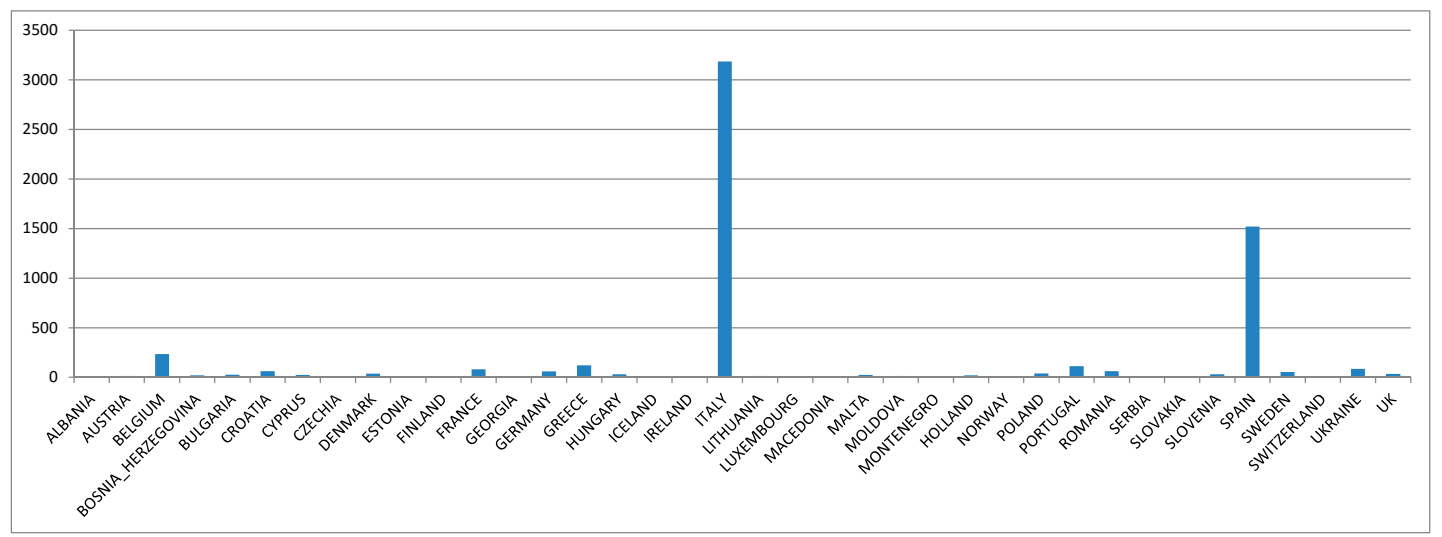

Figure 1. Action Plans in EU Member States (processing from: https://www.covenantofmayors.eu/, 2019).

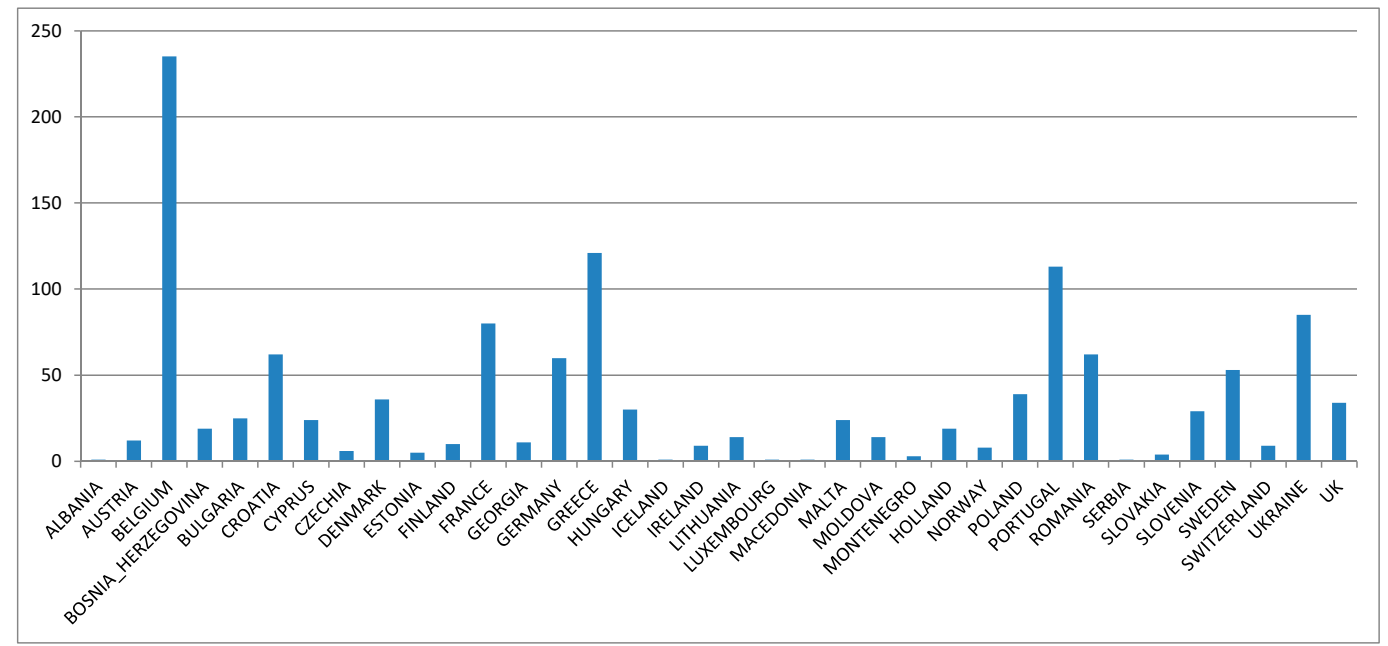

Figure 2. Action Plans in EU Member States without Italy and Spain (processing from: https: //www.covenantofmayors.eu/, 2019).

The authors analyze different adaptation plans in Europe at urban and metropolitan level (Berlin, Paris, Bologna...). In this regard, the Covenant of Mayors for Climate and Energy platform is initially consulted. The risks associated with climate change considered in these plans are different according to the physical and geomorphological characteristics of urban areas. These risks concern:

- Flood risk: connected to the high anthropization and the soil sealing, which prevent the infiltration of rain into the soil;

- Landslide risk: related to natural factors, such as geological and geomorphological conformation, it is strongly influenced by the anthropic modification of the territory and by the presence of goods and people in the areas at risk;

- Erosion risk: related both to natural causes such as sea level rise, and anthropogenic causes such as the increase in urbanization in the coastal strip for tourism and industrial purposes.

Adaptation plans incorporate actions aimed at reducing the vulnerability to climate change; mitigation plans consider actions to decrease greenhouse gas emissions [46,47]. Nevertheless, the adaptation plans in force are "new" tools drawn up by local governments and they are still in small numbers compared to mitigation plans. To be more effective, these plans should integrate the mitigation and adaptation approach.

Italy introduced the Climate Change Adaptation Plan in 2017. Figure 3 shows the diagram relating to the methodological approach studied to define climate change risks. The proposed risk 
index considers: the hazard, measured by a series of indicators referring to future climatic anomalies; the exposure and the risk perception, identified through a series of territorial indicators that detect both the presence of natural, human, and economic capital potentially exposed to climatic hazards and the perception of the various areas to damage; and finally, the ability to adapt [48].

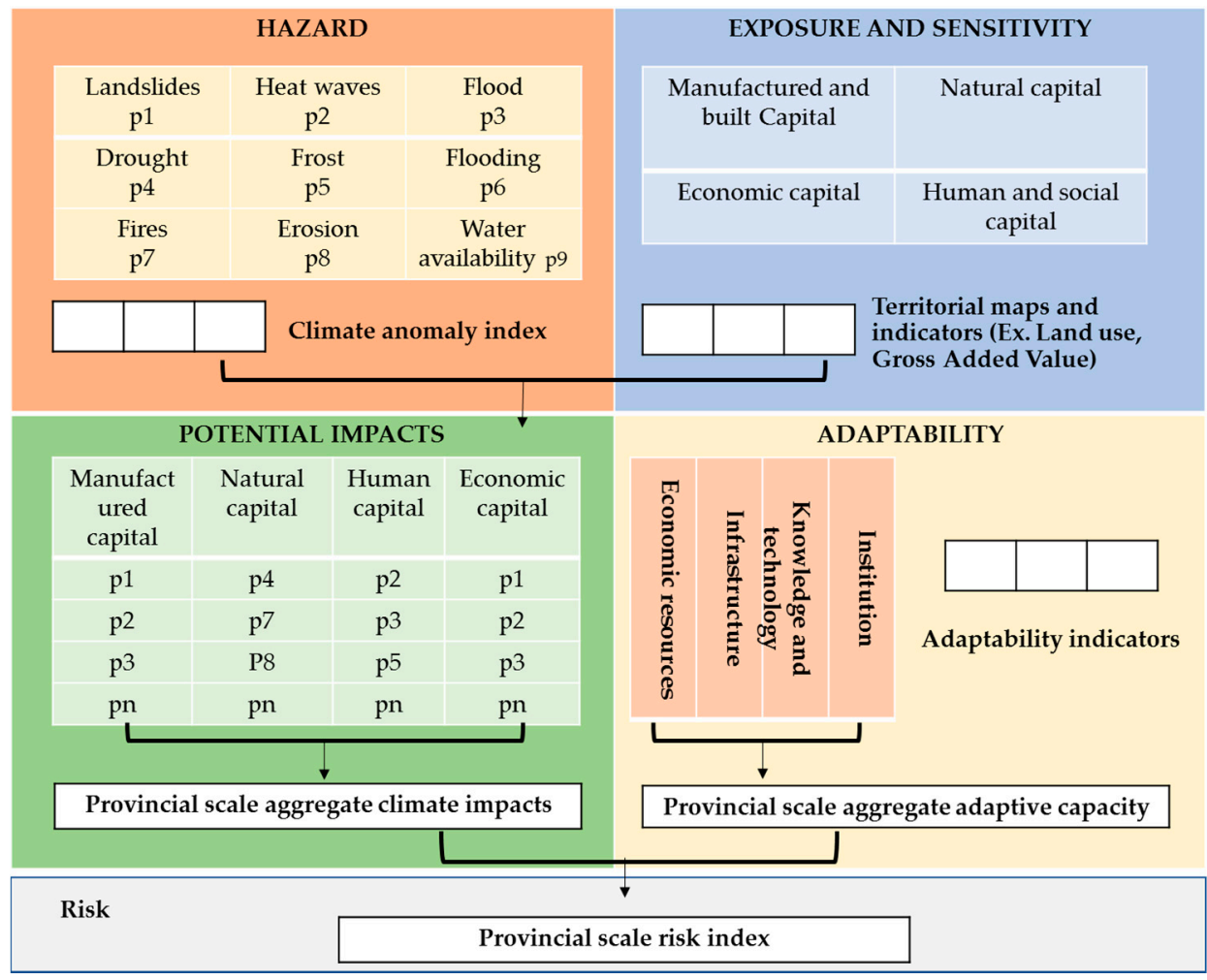

Figure 3. Scheme of the methodology proposed to define climate change risk in the Italian adaptation plan (translation from Italian Climate Change Adaptation Plan, 2017).

This paper focuses on the Urban Emergency Plan, because it is mandatory at European level-according to art. 6 of 1313/2013/EU of the European Parliament and of the Council on a Union Civil Protection Mechanism, as amended by Decision 2019/420—and for all Italian municipalities—according to the law 100/12. Emergency plans should aim at correlating different risk evaluations to provide a comprehensive emergency programme for people and territorial safety [41]. Currently, the Urban Emergency Plan does not include appropriate preventive measures to reduce the level of risk, but focuses on emergency management and rescue operations.

The Italian civil protection system, analyzed below, has become an example for many other nations. Over the past decade, it has developed as a result of many disastrous events and territorial interventions. The Urban Emergency Plan analyzes the different risk scenarios that may affect the city separately. This way, in case of danger, the administration knows: what is happening and what will happen; the interventions needed to mitigate the damage; the resources required; the main priority actions. An Urban Emergency Plan is divided in four different parts: territorial analysis; definition of local civil protection structures; risk scenario studies; intervention models definition. The risk scenario is the result of a process of analysis and overlap of the data obtained from the study of the territorial elements exposed to risk and all the possible hazardous situations. Therefore, a risk scenario includes a summary description of the event and a map of the areas considered most at risk for hazards and/or exposure. The plan considers only hazard analysis and exposure assessment. Regarding the hazard analysis, for each type of expected risk and territorial area, the plan identifies the relationship between the intensity of the expected event and the return time within which is statistically expected. To assess the territorial elements exposed to risk, all the places with public or private importance are catalogued, 
including administrative and operational structures and crowded buildings or squares. Starting from these scenarios, the Urban Emergency Plan defines the monitoring activities, the intervention model, the operational procedures, and the areas necessary for operative procedures for a correct emergency management.

\section{Materials and Methods}

The authors propose a review of the Urban Emergency Plan as a sector plan to support urban planning at the local level, aimed at building resilience in cities. The document therefore proposes an approach that introduces the concept of resilience and various actions for risk prevention and adaptation to climate change considering not only the emergency phase. The risk scenario tool was then analyzed, considering, in addition to the hazard and exposure variable, vulnerability and time as fundamental features for creating dynamic scenarios.

In this paper, a first application of the proposed approach to an Italian municipality is presented. This approach is in line with the European Union strategy for cooperation in the civil protection field. Indeed, European civil protection actions are not intended to replace national programmes but are based on the subsidiarity principle, according to which EU actions must always be developed "as much as possible" at local level. The case studies at the local scale are of special interest, since cities are the spaces of people's everyday lives, where experiential knowledge and face-to-face transactions take place [49-51]. A further innovative aspect introduced is the quadruple helix concept-according to which the involvement of four main actors (public authorities, research, enterprises, and citizens) is necessary to achieve a common goal-to foster the creation of resilient realities. The involvement, and therefore the participation, of the four identified players is fundamental in all phases of risk management.

An extract of the application of the research carried out by the authors for the Genoa case (Italy) is shown below to demonstrate how the city resilience does not depend only on the actions carried out by public authorities but it requires the joint work of all actors living or working in a city. The case study was chosen because it represents an internationally famous case due to devastating events that have involved Genoa in recent years, such as the flood of 2011 (natural hazard) and the collapse of the Morandi bridge in 2018 (man-made disaster). This research aims at contributing to filling in the gap of the operationalization of urban resilience at the local planning level. The application of the approach and the analysis of the case study, developed in the paper, can provide tangible example of the transition to urban resilience [52], shifting from a picture to a real display of resilience implementation into planning practice.

According to the "learning-by-doing" approach $[53,54]$, an experience at the local level is analyzed here to highlight the strategies implemented for enhancing urban resilience. The results can help other cities around the world to increase their resilience in the post-emergency phase, but also to promote resilience and sustainable development during the peace period.

\section{Methodology}

This paper presents a new methodological approach for the implementation of a resilient Urban Emergency Plans intended as a sectoral plan to support the urban land-use planning (Figure 4). This revised plan aims to improve resilience in cities by considering the ability to adapt to change as resilience [55]. The intrinsic changing and non-linear nature of social-ecological systems in time and space [28,56] implies the existence of multiple pathways towards resilience [18]. Thus, there is no "definite strategy" for resilience, but a transitioning to resilience [57] that implies multiple strategies in time and space in an evolutionary resilience framework.

The innovative aspect introduced by the approach concerns the integration of the quadruple helix concept-for a multi-stakeholder governance process-with the development of dynamic scenarios-according to a multi-scale criterion which considers time and space to support the process decision. These aspects are closely related and should be considered in all phases of risk management: from the planning (knowledge/analysis/choice of objectives, strategies, actions, times, 
actors, funding), implementation, and monitoring phase of the plan, to the management of the emergency and post-emergency phase. The proposed Emergency Plan reduces risk and increases resilience by identifying specific scenarios and actions that each of the actors-public authorities, research, enterprises, and citizens—can implement.

Risk scenarios are important to imagine the future danger situation in order to manage it [58,59]. The scenario is probably one of the main cognitive tools used to consider possible damages against natural and man-made risks and therefore to correctly manage the territory [60]. To design realist scenarios, it is important to know the initial situation of the territorial system and the effects that the actions of the plan may have on territorial resilience. In this way, the risk assessment based on the scenario becomes an analysis and assessment tool different from that obtained with a probabilistic analysis [61]. Scenarios in risk assessments are used for various purposes, such as land-use planning, measuring the consequences of a hazardous event, comparing different mitigation strategies, planning and managing civil protection operations. According to the proposed methodological approach, the dynamic scenarios are aimed at supporting the decision-making process towards a real territorial resilience. Risk scenarios are proposed to describe the future situations based on the scientific knowledge available at the time of their definition. For this reason, all risk scenarios should be updated and revised, for example, following the implementation of interventions to make the territory safer. The scenario-based risk assessment is not only essential to design the actions in the emergency phase, but also to define prevention and mitigation programmes. Each risk scenario must refer to a specific case study, because a single model, or method, cannot be directly applicable to other territorial contexts. The assessment of risk scenarios provides qualitative indications; the results obtained should not be considered as absolute but specific to the analysis carried out. In the literature, risk assessment, which is essential for the definition of risk scenarios, is calculated as a combination of three components: hazard, exposure, and vulnerability [62-65]. This study introduced another useful element in the definition of risk scenarios, time, to assess the exposure of territorial elements according to the time of day, months of the year, etc. For example, the exposure of a school changes in the morning compared to the evening, in winter compared to summer, because its users change over time. In this way, the exposure of people and things changes from static to dynamic. As a result, risk scenarios are also dynamic and change over time [66]. Thanks to GIS (Geographic Information System), it is possible to create territorial and environmental maps that can be updated and implemented in real time [67]. The risk scenarios, returned through the GIS, are preparatory to the definition of actions and structural or non-structural interventions necessary to mitigate the level of risk. These interventions must act on the individual components of the risk-hazard, vulnerability. and exposure, and plan the prevention, emergency, and post-emergency phases, addressing the different actors in a territory.

In particular, the methodological approach, studied to update the Urban Emergency Plan, proposes a multi-stakeholder governance process where all objectives, strategies, and actions are distinct for each of the key actors in the innovation processes: public authorities, research, enterprises, and citizens. These actors are part of the so-called quadruple helix, a model of interaction and interdependence necessary for territorial development [68] and thus also for increasing urban resilience.

The role of citizen participation in public planning processes has been widely discussed in the literature [69-73]. It has been stated that there are various advantages connected with citizen participation: better understanding of the problem to tailored solutions and more accepted outcomes, building of a wider consensus and self-transformation of values and preferences, reduction of hostility and increased public trust towards government (Forester, 1999; Irvin \& Stansbury, 2004; Agger, 2012). But there are also some limits to and downsides of citizen participation: citizen-participation programs might serve a marketing purpose (Irvin and Stansbury, 2004; p. 57); routinization of citizen participation may reduce the public pressure for reform; it can be costly and time consuming, and so on (Peattie, 1969; Russel \& Vidler, 2000) [74].

In this document, we delve into the importance of citizen participation and their collaboration with the other actors of the quadruple helix in the decision-making process. 
The concept of quadruple helix developed in the 2000s, starting from that of triple helix. The "triple helix" model, created in 1995 by Etzkowitz and Leydesdorff, came from the observation of the strategic importance in the development and marketing of new products and services that resides in the interaction between universities and research centers, public institutions, and the alliance of large, small, and medium enterprises (SMEs). This model has a very strong limit, namely that is not considering the user-in this case the citizen - as the fourth actor for innovation. Hence, there was a need to define a new model of innovation, the so-called "quadruple helix", that includes the citizens, creating a more user-centric approach (Figure 4). These models are mainly used in the marketing sector. However, in the proposed approach, the involvement of these four actors is the key for ensuring territorial resilience by creating a flexible community-based governance system [70]. The innovation introduced is based not only on the ability to have access to the knowledge and skills accumulated both internally and externally to the territorial system, but also on the ability to respond to changes on the economic, environmental, and social aspects. Urban resilience depends on the resilience of the individual components of the quadruple helix and it is essential for achieving the sustainability and the security of the territorial system.

The relationship and productive exchange of ideas and resources between all the main actors of the territory-in particular with its citizens-can promote and improve learning and innovation processes or facilitate them through the introduction of new specific behaviors. Innovative users can therefore play a driving force role that helps to determine the direction and the importance of innovative activities towards resilience [75].

The actors, involved individually or in groups, contribute to the implementation of the interventions-structural and non-structural-in the different risk phases. The objective is to lower the level of risk and increase the resilience and therefore territorial sustainability.
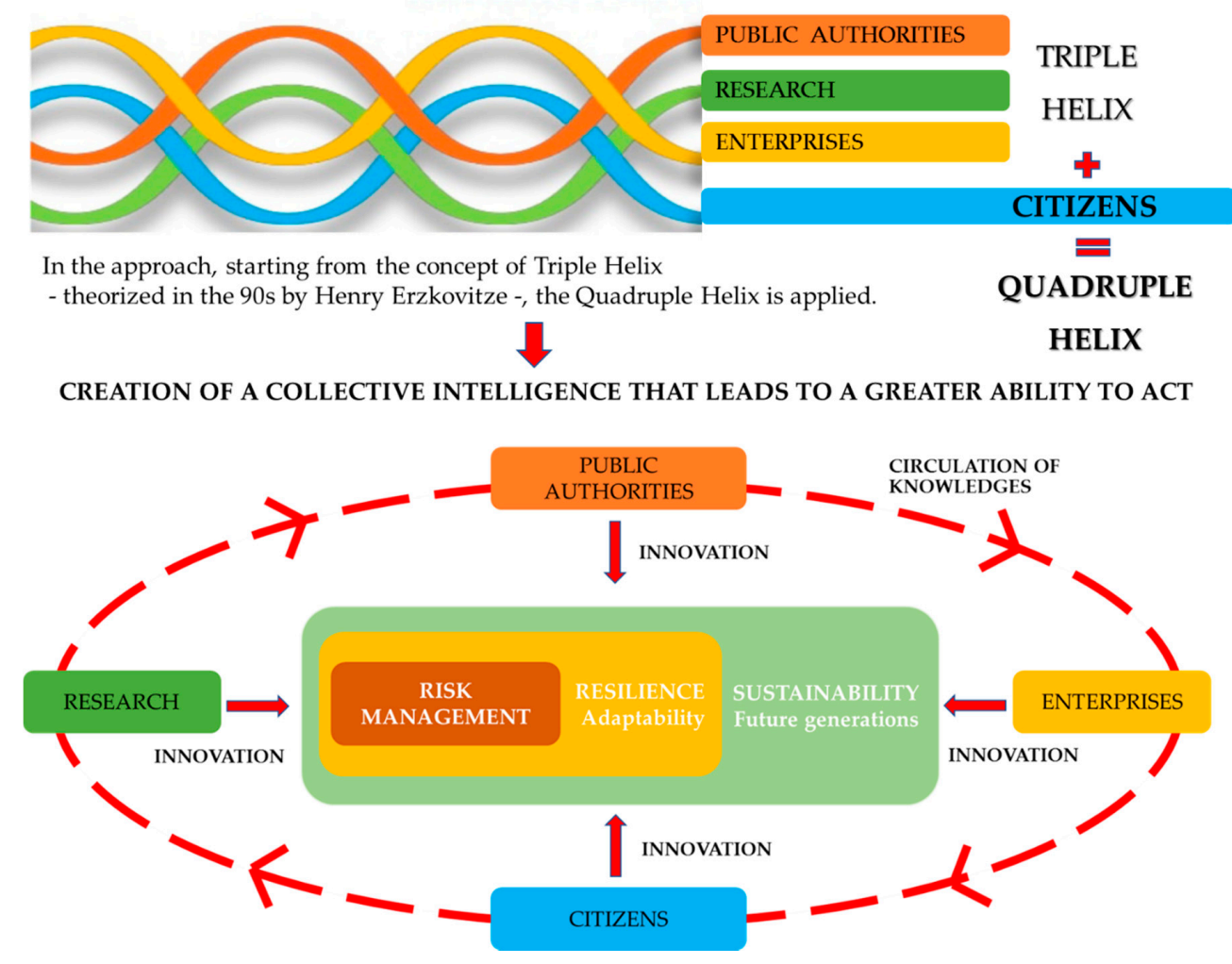

Figure 4. Correlation between risk, resilience, sustainability, and of the quadruple helix concept.

Given the importance of the synergy of the actions of the different territorial actors, the research proposes a series of interventions for each of the actors of the quadruple helix, differentiated according to the risk phases—prevention, emergency, and post-emergency —and the time component (Table 1 
shows an extract of the research). In this case, the temporality aspect concerns the timing from planning to implementation.

Table 1. Examples of interventions for each of the actors of the quadruple helix.

\begin{tabular}{|c|c|c|c|c|c|}
\hline \multirow{10}{*}{ 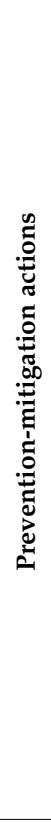 } & \multirow{5}{*}{ Structural } & Research & Public Authorities & Enterprises & Citizens \\
\hline & & \multicolumn{4}{|c|}{ Medium Period } \\
\hline & & $\begin{array}{l}\text { Design of structural } \\
\text { interventions and } \\
\text { land safety measures. }\end{array}$ & $\begin{array}{c}\text { Design and } \\
\text { implementation of } \\
\text { interventions to reduce } \\
\text { the level of risk in } \\
\text { sensitive areas and } \\
\text { buildings. }\end{array}$ & $\begin{array}{l}\text { Compliance with } \\
\text { safety regulations in } \\
\text { companies and } \\
\text { buildings. }\end{array}$ & $\begin{array}{l}\text { Prevention and risk } \\
\text { reduction } \\
\text { interventions in } \\
\text { private buildings. }\end{array}$ \\
\hline & & \multicolumn{3}{|c|}{$\begin{array}{l}\text { Moving public services (schools, hospitals, universities, etc.) from risk } \\
\text { areas to safe areas. }\end{array}$} & $\cdots$ \\
\hline & & $\ldots$ & $\ldots$ & $\ldots$ & $\ldots$ \\
\hline & \multirow{5}{*}{ Non-structural } & \multicolumn{4}{|c|}{ Short Period } \\
\hline & & \multicolumn{4}{|c|}{$\begin{array}{l}\text { Participation of all actors of the quadruple helix in consultation tables for the planning of } \\
\text { interventions to reduce the level of risk. }\end{array}$} \\
\hline & & \multicolumn{2}{|c|}{$\begin{array}{l}\text { Definition and implementation of information } \\
\text { and training activities for the population on } \\
\text { existing alert systems and on the behavior to } \\
\text { follow in case of risk. }\end{array}$} & \multicolumn{2}{|c|}{$\begin{array}{l}\text { Active participation in awareness-raising } \\
\text { meetings and training on how to behave in case } \\
\text { of risk. }\end{array}$} \\
\hline & & \multicolumn{2}{|c|}{$\begin{array}{l}\text { Studies on the possible relocation of services in } \\
\text { risk areas and on the change of use of buildings. }\end{array}$} & \multicolumn{2}{|c|}{$\begin{array}{l}\text { Change of residence and expropriation in case } \\
\text { your home is in a high-risk area. }\end{array}$} \\
\hline & & $\ldots$ & $\cdots$ & $\ldots$ & $\ldots$ \\
\hline \multirow{5}{*}{ 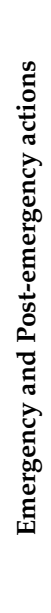 } & \multirow{5}{*}{$\begin{array}{c}\text { Structural } \\
\text { Non-structural }\end{array}$} & Research & Public Authorities & Enterprises & Citizens \\
\hline & & \multicolumn{2}{|c|}{$\begin{array}{l}\text { Activation of measures for the safety of } \\
\text { students, teaching and technical-administrative } \\
\text { staff inside university buildings. }\end{array}$} & $\begin{array}{l}\text { Positioning of } \\
\text { barriers or structures } \\
\text { to reduce the risk in } \\
\text { areas with great } \\
\text { vulnerability. }\end{array}$ & $\begin{array}{l}\text { Support for } \\
\text { institutions for the } \\
\text { implementation of } \\
\text { interventions to make } \\
\text { the territory safe. }\end{array}$ \\
\hline & & $\begin{array}{l}\text { Design of structural } \\
\text { renovation works. }\end{array}$ & $\begin{array}{l}\text { Design and } \\
\text { coordination of } \\
\text { structural renovation } \\
\text { interventions. }\end{array}$ & $\begin{array}{l}\text { Implementation of } \\
\text { renovation works for } \\
\text { the public and } \\
\text { private sector. }\end{array}$ & $\begin{array}{l}\text { Support for the } \\
\text { implementation of } \\
\text { renovation } \\
\text { interventions. }\end{array}$ \\
\hline & & $\begin{array}{l}\text { Information to the } \\
\text { university staff on } \\
\text { the behavior and } \\
\text { procedures to follow. }\end{array}$ & $\begin{array}{c}\text { Activation of the } \\
\text { municipal operational } \\
\text { center and civil } \\
\text { protection } \\
\text { organization. Provide } \\
\text { funding. }\end{array}$ & $\begin{array}{l}\text { Informing employees } \\
\text { of the behavior and } \\
\text { procedures to be } \\
\text { followed. }\end{array}$ & Self-protection actions. \\
\hline & & $\ldots$ & $\ldots$ & $\ldots$ & $\ldots$ \\
\hline
\end{tabular}

Each scenario is associated with specific interventions, included in the plan, that should be updated in order to verify if the action has led to an effective improvement of the resilience level. In the literature there are several examples to evaluate urban resilience [76,77]. After considering the main methods in the literature and the research objectives, this study identified the following macro-sectors for the assessment of urban resilience: ecological environment $[78,79]$, safety, mobility and transport, education, health, public spaces, socio-economic context, and actors involved. Each actor of the quadruple helix is responsible for the implementation of the actions foreseen in the plan. Research, enterprises, public authorities, and citizens work together to increase urban resilience. To assess the level of resilience, a quali-quantitative analysis is developed. This analysis is based on a study done by the Lombardy Region (Strategic Environmental Assessment of the Regional Operational Programme of the European Regional Development Fund -ERDF ROP- 2014-2020) [80]. For each of the chosen territorial areas, the elements of vulnerability and resilience that characterize these zones (degradation and quality) and the external factors that can influence these elements (pressures and responses, or policies, unplanned changes and trends) are analyzed (Figure 5). The concepts of vulnerability and 
resilience are treated as elements to build the ongoing territorial dynamics over time and the response capacities of the various territorial areas and actors. This study was developed through a "vulnerability and resilience analysis"; an atypical SWOT (Strengths, Weaknesses, Opportunities, Threats) analysis. The SWOT is aimed at focusing on the strengths and weaknesses of the reference context, as well as the related opportunities and threats linked to the hypothesis of development underway [81]. This analysis summarizes the general knowledge framework on the resources, vocations and critical issues that characterize a territory, in order to identify the areas and activities necessary to improve risk resilience.

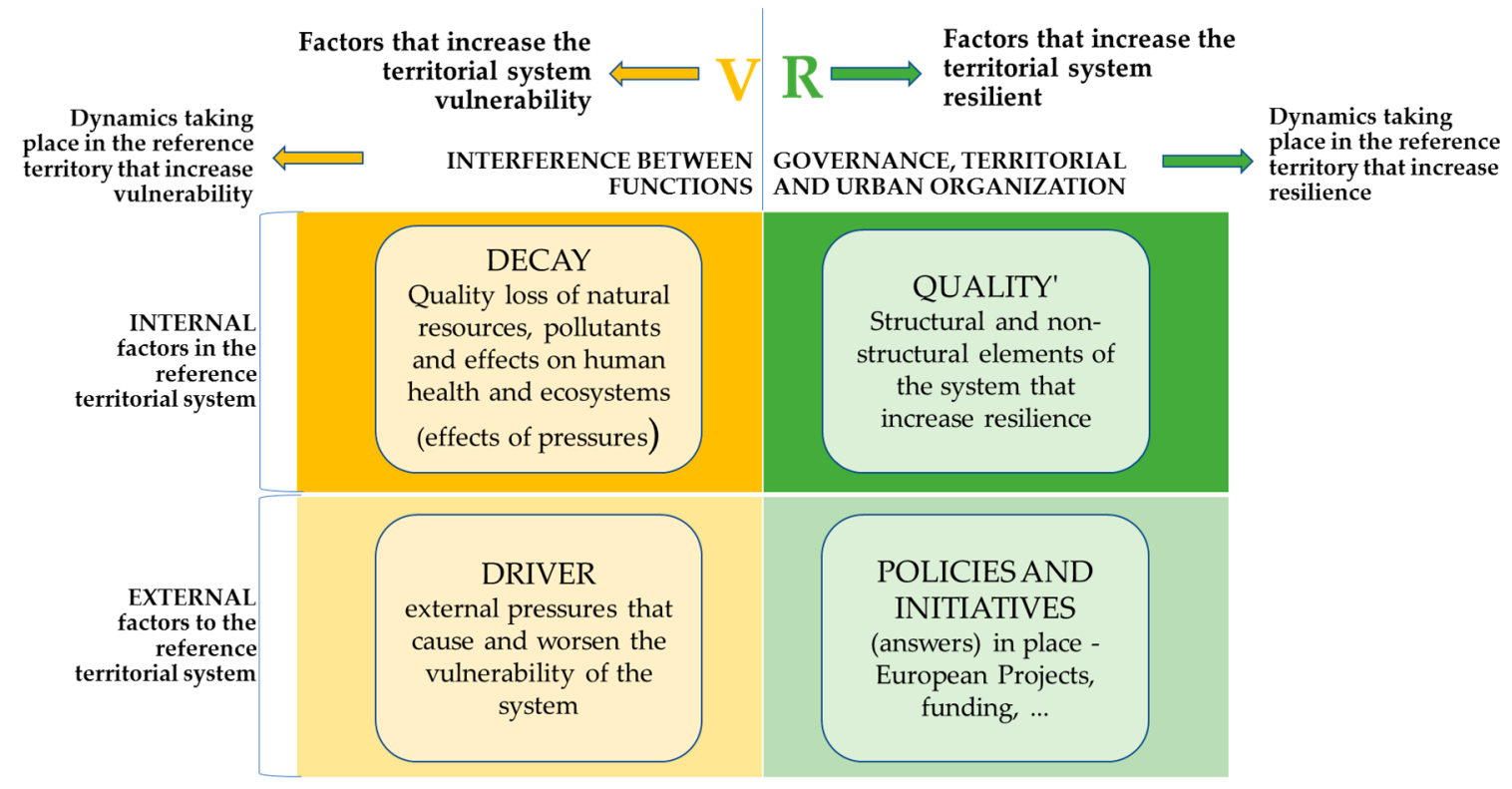

Figure 5. Structure of the vulnerability and resilience analysis.

Considering a specific macro-sector, for each action envisaged it is necessary to evaluate the impacts of each quadruple helix actor. These impacts can be positive (score 1), negative (score -1 ) or neutral (score 0 ), depending on whether the actors involved have carried out effective or ineffective actions or have decided not to act [82]. Therefore, an urban system can react in a positive manner to a disaster if there is a synergy among these four actors. Then, there are multiscale relationships between the resilience indicators that concern the various territorial scales investigated and the four actors considered [83]. The efficiency of the intervention can be monitored by recalculating the value of the resilience index and comparing it with the initial situation [84]. The results obtained through simulations can constitute a sort of "diagnostic evaluation" aimed at directing ordinary and strategic planning and territorial management choices [85].

\section{Application and Results}

The paper, starting from the approach described in paragraph 2, aimed at demonstrating the importance of the role of the quadruple helix - or rather, the cooperation between public authorities, research, enterprises, and citizens- to foster the development of resilient cities to calamitous events, whether of natural or human origin. Resilient planning must define actions able to: prevent and mitigate risk situations; manage emergencies by establishing procedures and structures; and enhance the adaptation of the disrupted system. Indeed, the resilience of a reality depends on the overall adaptation of the urban system.

The proposed methodology was applied to the Genoa case study. Genoa was chosen because after several calamitous events the city has shown, thanks to the post-event collaboration of the main actors of the quadruple helix and in particular of the population, a rapid recovery and therefore a good resilience. This aspect that occurred in the post-emergency phase must also be achieved in the 
prevention phase, hence the importance of defining different actions in the prevention and emergency phase characterized by the synergy of the Quadruple helix.

Genoa, according to the "learning by doing" approach, represents a good example to analyze in order to learn how the city reacted resiliently to natural and artificial events thanks to the collaboration of all the actors of the quadruple helix. In addition, from 2019, the City of Genoa is officially the first city in Europe to activate collaboration with DRMKC technicians (Disaster Risk Management Knowledge Center) of the Joint Research Center of the European Commission. This collaboration was born to implement a new platform, the Risk Data Hub, to develop prevention policies and to prepare changes needed according to the current and future risk scenarios. This collaboration is fundamental to the possible inclusion of city of Genoa in the world panel of the 100 Resilient Cities coordinated by the prestigious Rockefeller Foundation. The Genoese initiative also gained the interest of the National Department of Civil Protection (DPC) which, as part of the "Network of resilient cities" program, chose it as a representative local case for international activities [86].

In recent years, Genoa has been facing different types of hydraulic risk, such as floods and inundation. In fact, since the 1935s, there have been several events that have affected the city, more than 84 between landslides and floods (floods in the historic center, floods of the streams Bisagno, Fereggiano, Polcevera, Cerusa, etc.), which have caused 86 dead and missing (Figure 6) $[87,88]$. The morphology and hydro-geological characteristics of the territory are not the main cause; in fact, an important role is played by urbanization that has interfered negatively with watercourses.

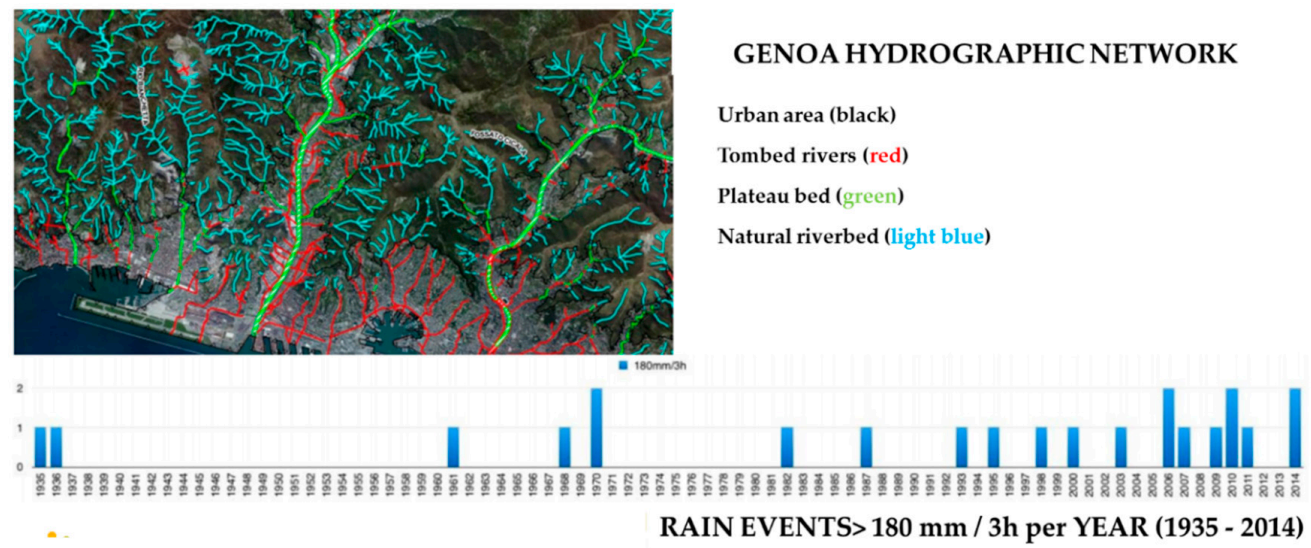

(a)

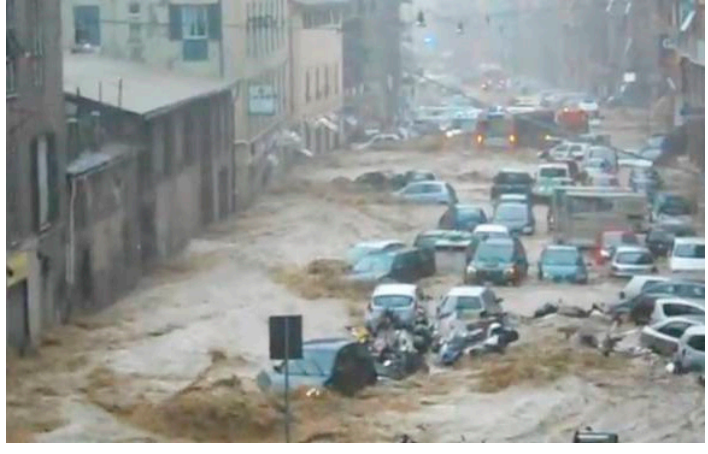

(b)

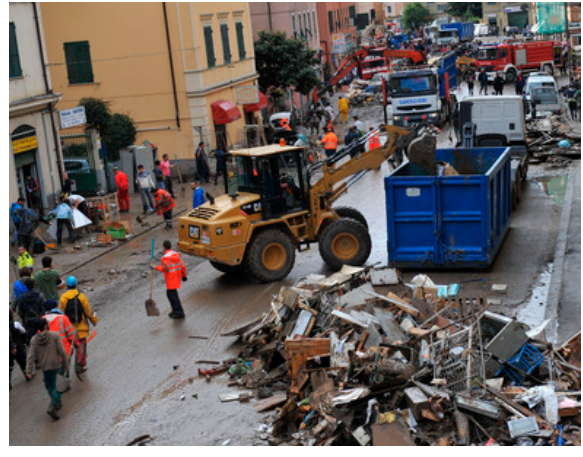

(c)

Figure 6. (a) Genoa hydrographic network (source: Urban Agenda for UE, 2019), (b) via Fereggiano during the flood of November 2011 (source: Genova.24.it); (c) Via Fereggiano post-emergency (source: Ansa.it).

Genoa is sadly remembered also for the anthropic risk. The collapse of the Morandi Bridge, an important viaduct over the Polcevera torrent, represents the main negative event due to human 
neglect (Figure 7). On August 2018, the partial collapse of this infrastructure caused the death of 43 people, the interruption of the main connector between two highways of international relevance (A7 and A10), the suspension of the railway line to the port and of some of the main roads connecting the Val Polcevera with the rest of the City. It can therefore be said that the direct impacts linked to this event have been substantial. Indirect impacts have been also significant. These impacts concern economic, social, and environmental aspects depending on the scale of the urban system involved: the city, the whole valley, or the district under the bridge.

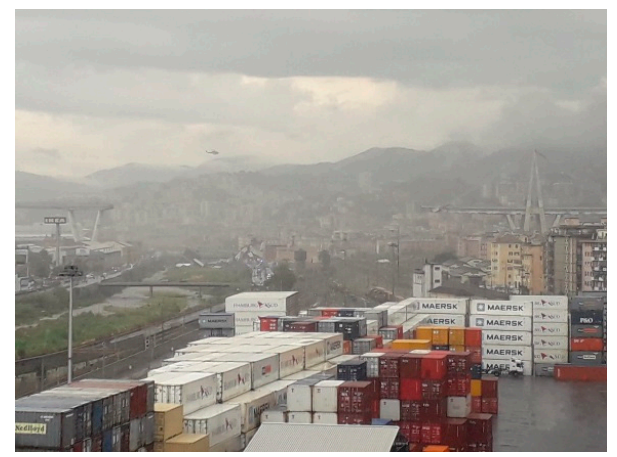

(a)

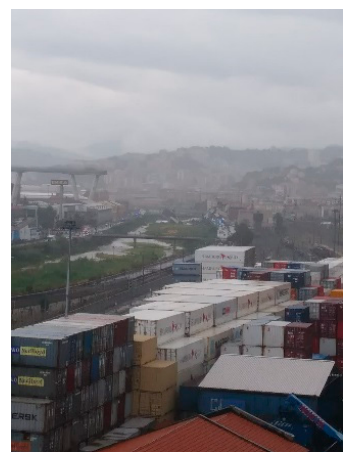

(b)

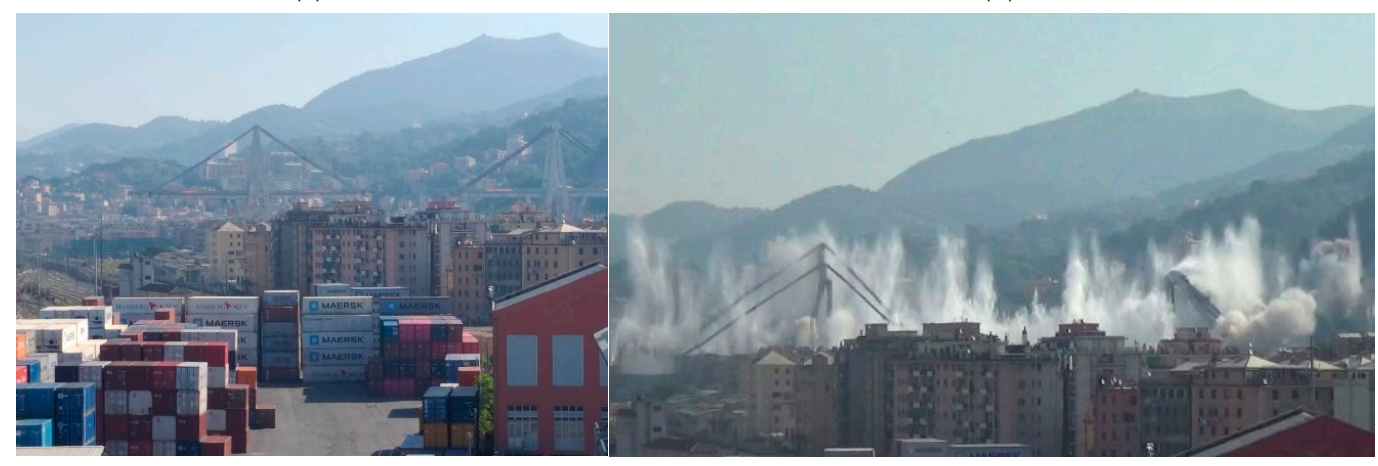

(c)

(d)

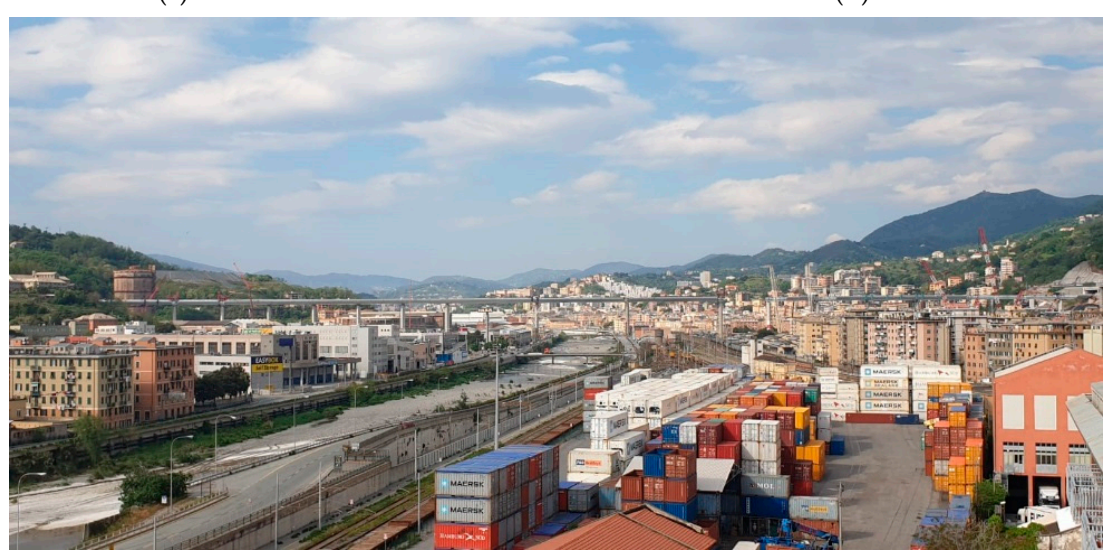

(e)

Figure 7. Image after the collapse of the Morandi bridge (August 2018-April 2020). (a) Collapse of the Morandi Bridge-14 August 2018. The post-emergence in Val Polcevera: demolition of the bridge (c) 20 June 2019; (d) 28 June 2019. (e) Reconstruction new bridge-22 April 2020.

In both types of risk, hydraulic and anthropic, the resilience of the Genoese territory was manifested through the resilience of the individual actors of the quadruple helix. The adaptation therefore took place thanks to the integration and overlapping of the actions that each of the main actors that are 
present in the territorial system implemented. Resilience is, in fact, a systemic functionality that resides at the level of the system analyzed.

Genoa's resilience manifested itself in the emergency and post-emergency phases, with a rapid recovery of activities and the restoration of existing functions that allowed the city not to stop. As a result of the calamitous events that have involved the city, there are many resilience actions that can be reported for the prevention phase, i.e., to be applied in everyday life. In the case of hydraulic risk, experiences have led to consideration of the importance of resilience in the preventive phase. Some structural and, above all, non-structural interventions have been developed, such as the new preventive and warning measures and an important public awareness campaign. Following the approval of Regional Resolution no. 1057 of 5 October 2015, the Municipality of Genoa introduced the classification of alerts according to the colors yellow-orange-red. Based on the color code, several prevention measures established in the Urban Emergency Plan come into force and all citizens are invited to contribute by adopting the behavioral rules of self-protection. In addition, a warning system via SMS has been activated to inform citizens in good time about the type of alert. The municipality has also launched several awareness-raising actions to make the territory more ready to respond to calamitous events. Awareness campaigns are extremely important for the success of an emergency plan, since a population fully aware of the danger can behave properly and cooperate with the rescue forces.

Even in the case of the Morandi bridge, there were many resilient actions taken. Here are some of the main actions done that demonstrate the resilience of Genoa in the post-emergency phase (all the information was taken from official documents of the Municipality of Genoa and newspaper articles):

- The school calendar has not changed: lessons started as planned on 14 September 2019 (in case of strong earthquakes teaching has always been suspended);

- People living outside the red areas (areas near the collapsed bridge) continued to go to work (except in some cases they started working at home);

- In the 5-6 months following the disaster, citizens going to work increased their travel time by at least one hour and changed their travel habits by favoring public transport (car use was difficult due to traffic following the collapse of the bridge and the closure of the roads in the red areas);

- After a week 11 families already had new homes, and within three months after the collapse the housing emergency ended;

- One month after the tragedy, via Della Superba was completed and opened, a new road inside the port area for trucks;

- Five months after, Lungo Mare Canepa was created to connect the two highways that were separated after the bridge collapsed;

- Less than a year after, the remaining parts of the Morandi bridge were demolished and the debris removed;

- $\quad$ After four months the project for the new bridge was approved;

- $\quad$ Less than two years later, the new bridge will be completed-scheduled to open in May 2020.

The collapse of the bridge modified the movement of goods and people, showing how road networks play a fundamental role in territorial development, in the ability to connect people with work, and to make local communities recognize them as a single entity. The population, among the actors of the quadruple helix, is the one that has shown to be more resilient by changing its mobility habits. In fact, many people had to change the means of transport used and their journey times for daily home-work or home-school trips [89]. According to a survey by Confindustria, General Confederation of Italian Industry, $44 \%$ of workers living in Val Polcevera increased the home-work journey by about $30 \mathrm{~min}, 32 \%$ by about $15 \mathrm{~min}$, and the remaining $24 \%$ by $45 \mathrm{~min}$ and more.

The resilience shown by Genoa emerged spontaneously as a reaction to the events that occurred; this can be demonstrated by analyzing what happened in the post-events. This is what makes measurement and operationalization of resilience such a challenge. The proposed methodology intends to constitute a tool not to leave resilience to chance but to guide it through planning. This 
means considering resilience in prevention, emergency, and post-emergency strategies. Our goal was to explore the temporal and spatial evolution of urban resilience from the point of view of the city. To calculate the level of resilience, before and after the crisis, a qualitative-quantitative analysis was developed, based on the evaluation of the impacts of the actions of the actors involved:

- $\quad$ Positive, if they have performed effective actions (score 1);

- $\quad$ Neutral, if they have decided not to act (score 0);

- Negative, if they have performed ineffective actions (score -1).

In the first case, when the impact is positive, the degree of resilience is higher than in the peace period and the system maintained its key functions or even improved them.

The level of resilience of the city of Genoa increased spontaneously after the flood of 2011 and the collapse of the Morandi bridge in 2018 from the starting level to an intermediate level.

Figure 8 shows an extract of the analysis developed for the assessment of resilience after the collapse of the bridge. The Polcevera valley and the district under the bridge were considered as the territorial sample.

\begin{tabular}{|c|c|}
\hline $\mathbf{R}$ & \\
\hline PUBLIC AUTHORITIES & Score \\
\hline - Regular start of schools & 1 \\
\hline - Realization of the road Lungo Mare Canepa in 5 months & 1 \\
\hline - Construction of the new bridge (less than two years after the collapse) & 1 \\
\hline $\begin{array}{l}\text { - Cooperation between the different institutional levels to speed up the design and construction } \\
\text { of the necessary works (debris disposal and construction of the new bridge) }\end{array}$ & 1 \\
\hline - Trains - higher frequency, with the addition of a few trains & -1 \\
\hline - Extension of the opening hours of the metro & 1 \\
\hline - Shuttles for students & 0 \\
\hline - New free bus line & -1 \\
\hline - Free means of transport & -1 \\
\hline - Aid traders & 1 \\
\hline - National and regional funding & .... \\
\hline RESEARCH & \\
\hline - Support for students living in Polcevera Valley & 1 \\
\hline - Special lectures & -1 \\
\hline - Participation in the Sustainable Urban Mobility Plan (SUMP) definition & 1 \\
\hline CITIZENS & $\cdots$ \\
\hline $\begin{array}{l}\text { - New daily habits (new means of transport and actions: early wake-up, late evening returns, } \\
\text { limitation in common activities, etc.) }\end{array}$ & 1 \\
\hline - Citizens' cooperation & 1 \\
\hline $\begin{array}{l}\text { - Shift towards sustainable mobility: limitation on car use and increasing journeys with local } \\
\text { public transport (bus, train, metro, pedestrian, etc.) }\end{array}$ & 1 \\
\hline - Little participation from the Genoese living in other parts of the city & -1 \\
\hline ENTERPRISES & \\
\hline - Setting up of non-stop work for all the companies charged with building new infrastructures, & 1 \\
\hline including the bridge & 1 \\
\hline - Corporate car sharing & 1 \\
\hline - Smart working & 1 \\
\hline - Bankruptcy of small businesses & -1 \\
\hline & $\ldots$ \\
\hline
\end{tabular}

Figure 8. Genoa resilience analysis after the collapse of the Morandi bridge.

The positive actions resulting from the resilience assessment (post emergency) described above have been proposed within the Genoa Urban Emergency Plan to increase local resilience during the peace period. Table 2 shows an extract of the research carried out. 
Table 2. Examples of integrations to improve resilience in Genoa Urban Emergency Plan.

\begin{tabular}{ll}
\hline \multicolumn{1}{c}{ Urban Emergency Plan Genoa } & \multicolumn{1}{c}{ Suggested Integrations to Improve Urban Resilience } \\
\hline 1. Criteria for risk assessment & $\begin{array}{l}\text { Inclusion of the prevention phase and the resilience } \\
\text { concept (the plan in force considers only the emergency } \\
\text { and the post-emergency phases). The plan should assess } \\
\text { the starting resilience index of the city and propose } \\
\text { different actions to improve this index. } \\
\text { The plan considers only the municipal actors, while it } \\
\text { should analyze the various contributions of each of the } \\
\text { actors of the quadruple helix. }\end{array}$ \\
2. Municipal operational phases & $\begin{array}{l}\text { It is advisable to insert a paragraph dedicated to } \\
\text { prevention and resilience not only the emergency and } \\
\text { post-emergency phases. } \\
\text { It is important to organize meetings with each of the actors } \\
\text { of the quadruple helix to share and implement the contents } \\
\text { though a participatory design approach.. }\end{array}$ \\
\hline 4. Plan implementation and monitoring &
\end{tabular}

The Urban Emergency Plan should propose different actions to increase local resilience level. According to the methodology proposed by the paper, each actor of the quadruple helix-public authorities, research, enterprises, and citizens-is responsible for the implementation of the actions foreseen in the plan.

The application shows that the resilience of an urban system responds holistically; that is, it cannot be explained exclusively through its individual components, since the functional sum of the parts is always greater, or in any case different, of the same parts taken individually $[90,91]$. The four different scores that make up the resilience index do not capture the "absolute resilience" but consider the contribution that each actor can make (in the planning phase or in the post-event phase). The four actors work together to increase urban resilience. Thanks to a series of strategies-which coordinate the possible interventions of each of the four actors over time and space-included in the new urban emergency plan, it is possible to achieve an optimal level of resilience (Figure 9). This level corresponds to a safety standard for all the people and thing exposed to risk (people, historical heritage, built, etc.). Urban systems are indeed the result of the interaction between the natural and morphological aspects with the different actors who live, work, study, or govern it [92].

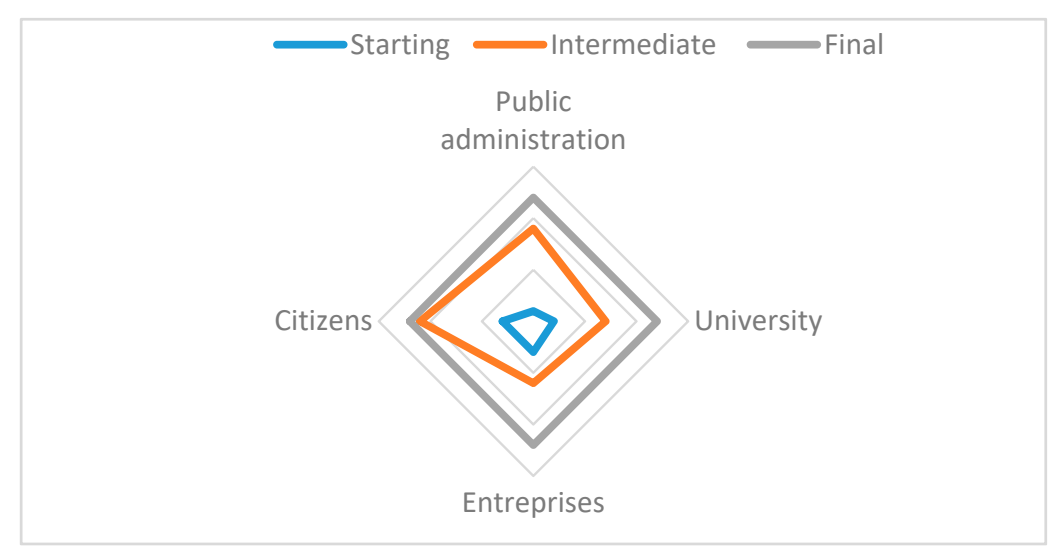

Figure 9. The resilience index of Genoa before (starting) and after (intermediate) the implementation of the actions foreseen in the Urban Emergency Plan. The final index represents the optimal level of resilience to be achieved.

\section{Discussion and Conclusions}

The proposed methodology, that considers the involvement of the different actors of the quadruple helix to improve local resilience, can constitute a new DSS (Decision Support System) (Figure 10). This methodology can indeed support local administrations in identifying the interventions, 
the constraints that must be observed in potentially endangered areas, and the technical standards aimed at guaranteeing the resilience of the population, buildings, and ecosystems [93-95].

The integration of resilience, and so sustainability criteria, to urban dimension should not be just an environmental benefit, but an alternative to generate better habitability in cities, increasing the quality of life. If we really want to pursue a deep change, we need to embrace new approaches to understand cities' complexity. This complexity requires the definition of new strategies to redirect urbanization trends towards a resilient horizon. This change must be supported by the creation of holistic knowledge [96]. The holistic characteristics were introduced by the Santa Fe Institute, a research center in the USA:

- Multidisciplinary approach;

- Analysis of the behavior of complex systems;

- Recognition of the feedback mechanism between systems as a crucial element for understanding their behavior.

In the approach proposed, the multidisciplinarity is represented by the introduction of a multi-stakeholder governance process thanks to the quadruple helix principle. The new resilient and dynamic scenarios-according to the multi-scale criterion that considers time and space-can play a fundamental role in the analysis of the urban contest as a complex system.

Quadruple helix principle and dynamic scenarios, included in the Urban Emergency Plan, are related to both the emergency and post-emergency phases, but also in the prevention phase. In this way, planning plays a central role in orienting the choices of local government towards solutions that consider risk reduction, the increase of resilience, and therefore the sustainability of the territory. The proposed emergency plan identifies specific structural and non-structural interventions that each of the actors-public authorities, research, enterprises, and citizens—can implement according to the risk phases and the time component. What is important is the sharing and circulation of knowledge between the actors, involved individually or in groups, to help achieve the goal of resilience.

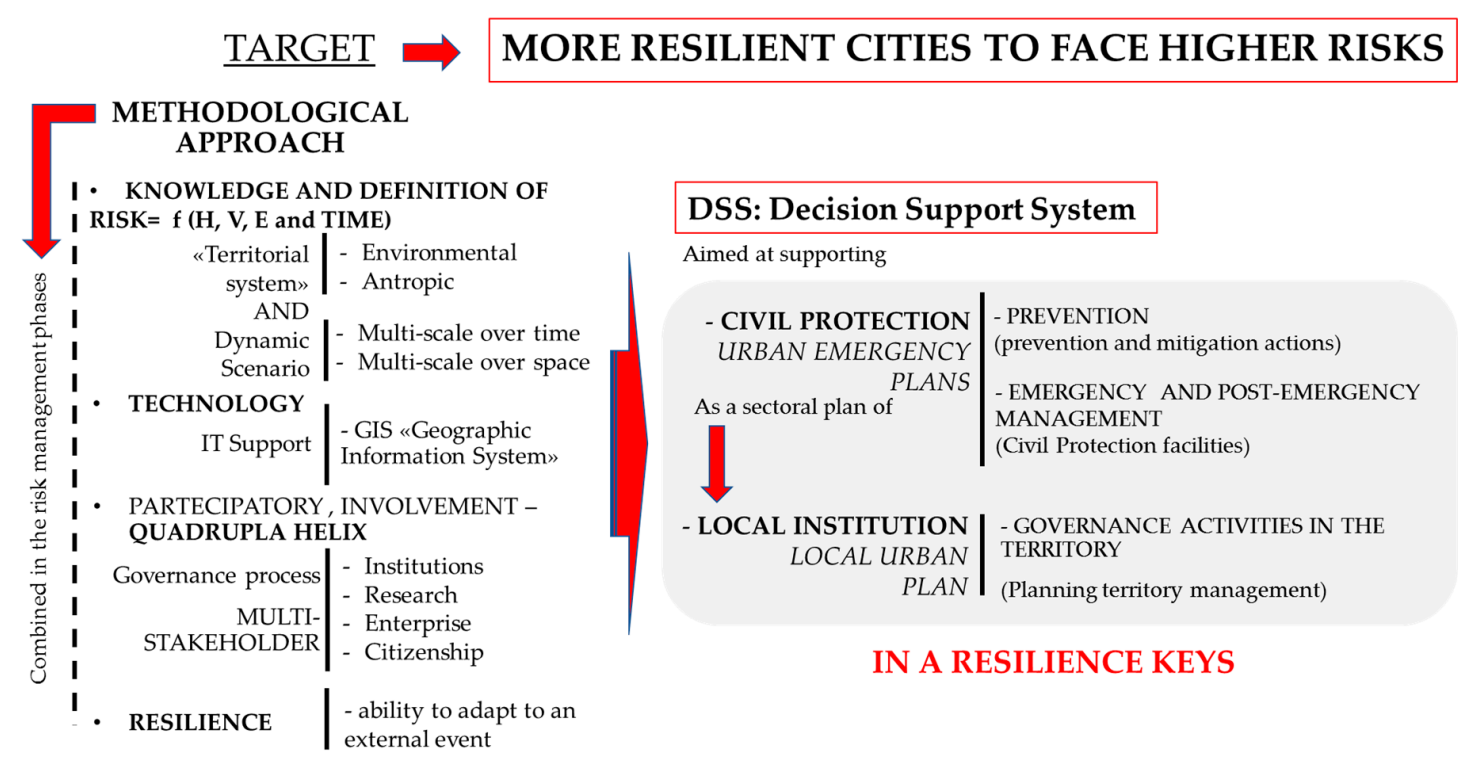

Figure 10. The approach for more resilient cities to natural and man-made risks.

The third aspect of the holistic research is the feedback mechanism. According to the study presented, the "learning by doing" approach was followed. The analysis of post-emergency resilience and the application of the methodology to the Genoa case study was proven to be useful for identifying specific actions for the four actors, also in the prevention phase and therefore for urban planning. A more important aspect that emerged in this research was the recognition of the holistic approach 
to respond to the challenge of resilience. This approach is fundamental to study a complex system such as that concerning the risk resilience analysis of a territorial system. Cities, being complexes of interdependent systems, cannot be understood by sectorial and disciplinary approaches alone [97]. In the holistic approach, systems are approached as coherent wholes whose component parts are best understood in context and in relation to one another and to the whole $[98,99]$. This practice is in contrast to a purely analytic tradition (sometimes called reductionism), which aims to understand systems by dividing them into smaller composing elements and gaining understanding of the system through understanding their elemental properties [100]. This paper therefore proposes an approach to resilience that starts from the innovation that each actor of the quadruple helix can bring. The resilience of territorial systems can therefore be calculated as a function of the resilience of all the actors involved.

$$
\begin{aligned}
& \text { Resilience }_{\text {Urban system }} \\
& =f\left(\text { Resilience }_{\text {PublicAuthorities }} ; \text { Resilience }_{\text {Research }} ; \text { Resilience }_{\text {Enterprises }} ; \text { Resilience }_{\text {Citizens }}\right)
\end{aligned}
$$

The "Smart Mature Resilience" project (founded by Horizon 2020 Programme of the European Union) can be considered a proof of what is proposed here. This project gathers experts from the cities of Bristol, Donostia/San Sebastian, Glasgow, Kristiansand, Riga, Rome, and Vejle to contribute to the development of a city-resilience maturity model and a risk assessment questionnaire. In this process two cross-cutting elements are monitored: stakeholder involvement and quality improvement. The greater the number of stakeholder types (including external stakeholders outside the city) involved in the resilience building process, the greater the effectiveness and the quality of the measures taken in the most virtuous cities. According to project guidelines, among the main characteristics that cities with a robust resilience level must have (the levels are: initial, moderate, advanced, robust, vertebrate) is precisely the development of a framework to manage resilience with a holistic approach [101,102].

In conclusion, the approach studied and the analysis of the case study of the city of Genoa-i.e., the collaboration of all the actors involved in order to adapt resiliently to natural and artificial events-may be useful for other cities that, in the framework of the Municipal Master Plan, have to face choices of territorial planning before a calamitous event occurs. The proposed approach therefore allows the Urban Emergency Plan to become a sector plan of the Municipal Urban Plan capable of encouraging the launch of resilient processes within a territorial system potentially vulnerable to calamitous events.

Author Contributions: Conceptualization of the methodology and supervision F.P.; methodology and first application support I.S., support to the application S.C. All authors have read and agreed to the published version of the manuscript.

Funding: This research received no external funding.

Conflicts of Interest: The authors declare no conflict of interest.

\section{References}

1. Gouldson, A.; Colenbrander, S.; Sudmant, A.; Papargyropoulou, E.; McAnulla, F.; Hall, S. Cities and climate change mitigation: Economic opportunities and governance challenges in Asia. Cities 2016, 54, 11-19. [CrossRef]

2. Rosenzweig, C.; Solecki, W.; Hammer, S.A.; Mehrotra, S. Climate Change and Cities: First Assessment Report of the Urban Climate; Cambridgde University Press: New York, NY, USA, 2011.

3. Corfee-Morlot, J.; Kamal-Chaoui, L.; Donovan, M.G.; Cochran, I.; Robert, A.; Teasdale, P.J. Cities, Climate Change and Multilevel Governance. In OECD Environment Working Papers, 14th ed.; OECD Publishing: Paris, France, 2009.

4. UCCRN. The future we don't want. In Urban Climate Change Research Network; Columbia University: New York, NY, USA, 2018.

5. Acuto, M. City leadership in global governance. Glob. Gov. 2013, 19, 481-498. [CrossRef]

6. Betsil, M.; Bulkely, H. Cities and the multilevel governance of global climate change. Glob. Gov. 2006, 12, 141-159. [CrossRef] 
7. Fraser, E.; Dougill, A.; Mabee, A.; Reed, M.; McAlpine, P. Bottom up and top down: Analysis of participatory processes for sustainability indicator identification as a pathway to community empowerment and sustainable environmental management. J. Environ. Manag. 2006, 78, 114-127. [CrossRef] [PubMed]

8. OECD. Cities and Climate Change; Organisation for Economic Cooperation and Development: Paris, France, 2010.

9. Gouldson, A.; Colenbrander, S.; McAnulla, F.; Sudmant, A.; Kerr, N.; Hall, S. Exploring the economic case for climate action in cities. Glob. Environ. Chang. 2015, 35, 93-105. [CrossRef]

10. IPCC. Climate Change 2014: Synthesis Report. Contribution of Working Groups I, II and III to the Fifth Assessment Report of the Intergovernmental Panel on Climate Change; IPCC: Geneva, Switzerland, 2014.

11. World Bank report: Cities and Climate Change: An Urgent Agenda; World Bank: Brussels, Belgium, 2010.

12. United Nation. 2018 Revision of World Urbanization Prospects; United Nations Department of Economic and Social Affairs: New York, NY, USA, 2018.

13. Ahern, J. From fail-safe to safe-to-fail: Sustainability and resilience in the new urban world. Landsc. Urban Plan. 2011, 100, 341-343. [CrossRef]

14. Alan, A.; Lew, P.T.; Chin, C.N. Community sustainability and resilience: Similarities, differences and indicators. Tour. Geogr. 2016, 18, 18-27.

15. Elmqvist, T.; Andersson, E.; Frantzeskaki, N. Sustainability and resilience for transformation in the urban century. Nat. Sustain. 2016, 2, 267-273. [CrossRef]

16. Walker, B.H.; Salt, D. Resilience Thinking. Sustaining Ecosystems and People in a Changing World; Island Press: Washington, DC, USA, 2006.

17. Bruntland, G.H. Our common future. In Report of the 1987 World Commission on Environment and Development; Oxford University Press: Oxford, UK, 1987.

18. Collier, M.J.; Nedovi'c-Budi'c, Z.; Aerts, J.; Connop, S.; Foley, D.; Foley, K.; Newport, D.; McQuaid, S.; Slaev, A.; Verburg, P. Transitioning to resilience and sustainability in urban communities. Cities 2013, 32, 21-28. [CrossRef]

19. Campbell, S. Green cities, growing cities, just cities? Urban planning and the contradictions of sustainable development. J. Am. Plan. Assoc. 1996, 62, 296-312.

20. Lele, S.M. Sustainable development: A critical review. World Dev. 1991, 19, 607-621. [CrossRef]

21. Redman, C.L. Should sustainability and resilience be combined or remain distinct pursuits? Ecol. Soc. 2014, 19,37-45. [CrossRef]

22. Marchese, D.; Reynolds, E.; Bates, M.E.; Morgan, H.; Spierre Clark, S.; Linkov, I. Resilience and sustainability: Similarities and differences in environmental management applications. Sci. Total Environ. 2017, 1275-1283. [CrossRef] [PubMed]

23. Carpenter, S.; Walker, B.; Anderies, J.M.; Abel, N. From metaphor to measurement: Resilience of what to what? Ecosystems 2001, 4, 765-778. [CrossRef]

24. Brown, K. Global environmental change I: A social turn for resilience? Prog. Hum. Geogr. 2013, 38, $107-117$. [CrossRef]

25. Cascio, J. The next big thing: Resilience. Foreign Policy 2009, 172, 92.

26. Meerow, S.; Newell, J.P. Resilience and complexity: A bibliometric review and prospects for industrial ecology. J. Ind. Ecol. 2015, 19, 236-251. [CrossRef]

27. Chandler, D.; Coaffee, J. The Routledge Handbook of International Resilience; Routledge: Abingdon, UK, 2016.

28. Pizzo, B. Problematizing resilience: Implications for planning theory and practice. Cities 2015, 43, $133-140$. [CrossRef]

29. Leichenko, R. Climate change and urban resilience. Curr. Opin. Environ. Sustain. 2011, 3, 164-168. [CrossRef]

30. Pierce, J.C.; Budd, W.; Lovrich, N.P. Resilience and sustainability in US urban areas. Environ. Polit. 2011, 20, 566-584. [CrossRef]

31. Solecki, W.; Leichenko, R.; O'Brien, K. Climate change adaptation strategies and disaster risk reduction in cities: Connections, contentions, synergies. Curr. Opin. Environ. Sustain. 2011, 3, 135-141. [CrossRef]

32. Zimmerman, R.; Faris, C. Climate change mitigation and adaptation in North American cities. Curr. Opin. Environ. Sustain. 2011, 3, 181-187. [CrossRef]

33. Collier, S.; Newell, J.P.; Melissa, S. Defining urban resilience: A review. Landsc. Urban Plan. 2016, 147, 38-49.

34. Wamsler, C.; Brink, E.; Rivera, C. Planning for climate change in urban areas: From theory to practice. J. Clean. Prod. 2013, 50, 68-81. [CrossRef] 
35. Paton, D. GNS Science Report 2007: Measuring and Monitoring Resilience in Auckland; GNS Science: Lower Hutt, New Zealand, 2007.

36. Paton, D.; Mamula-Seadon, L.; Selway, K. GNS Science Report 2013: Community Resilience in Christchurch: Adaptive Responses and Capacities during Earthquake Recovery; GNS Science: Lower Hutt, New Zealand, 2013.

37. Schwab, J.; Topping, K.C.; Eadie, C.C.; Deyle, R.E.; Smith, R.A. PAS Report No. 483/484: Planning for Post-Disaster Recovery and Reconstruction; American Planning Association: Chicago, IL, USA, 1998.

38. UN Division for Sustainable Development, Open Working Group Proposal for Sustainable Development Goals. 2014. Available online: http://sustainabledevelopment.un.org/sdgsproposal.html (accessed on 3 December 2014).

39. Suggested elements for the post-2015 framework for disaster risk reduction. Third United Nations World Conference on Disaster Risk Reduction Preparatory Committee; United Nations: Geneva, Switzerland, 2014.

40. Saunders, W.S.A.; Becker, J.S.A. Discussion of resilience and sustainability: Land use planning recovery from the Canterbury earthquake sequence, New Zealand. Int. J. Disaster Risk Reduct. 2015, 14, 73-81. [CrossRef]

41. Pilone, E.; Mussini, P.; Demichela, M.; Camuncoli, G. Municipal Emergency Plans in Italy: Requirements and drawbacks. Saf. Sci. 2016, 85, 163-170. [CrossRef]

42. UN/ISDR. Hyogo Framework for Action 2005-2015: Building the Resilience of Nations and Communities to Disasters; United Nations: New York, NY, USA, 2005.

43. Directive 2007/60/EC of 23 October 2007 on the Assessment and Management of Flood Risks; European Parliament and of the Council: Brussels, Belgium, 2007.

44. The EU Strategy on Adaptation to Climate Change; European Commission: Brussels, Belgium, 2013.

45. Pirlone, F.; Spadaro, I. Energy planning and sustainability, Encyclopedia of the UN Sustainable Development Goals. In Affordable and Clean Energy; Leal Filho, W., Gökçin Özuyar, P., Azul, A.M., Brandli, L., Wall, T., Eds.; Springer International Publishing in press: Basel, Switzerland, 2021; ISBN 978-3-319-95863-7. ISSN 2523-7403.

46. Reckien, D.; Flacke, J.; Dawson, R.J.; Heidrich, O.; Olazabal, M.; Foley, A.; Hamann, J.; Orru, H.; Salvia, M.; De Gregorio Hurtado, S.; et al. Climate change response in Europe: What's the reality? Analysis of adaptation and mitigation plans from 200 urban areas in 11 countries. Clim. Chang. 2014, 122, 331-340. [CrossRef]

47. Parry, M.L.; Canziani, O.F.; Palutikof, J.P. Technical Summary. In Climate Change 2007: Impacts, Adaptation and Vulnerability. Contribution of Working Group II to the Fourth Assessment Report of the Intergovernmental Panel on Climate Change; Parry, M.L., Canziani, O.F., Palutikof, J.P., van der Linden, P.J., Hanson, C.E., Eds.; Cambridge University Press: Cambridge, UK, 2007.

48. Italian Ministry for the Environment, Land and Sea (IMELS), National Climate Change Adaptation Plan, Italy. Available online: https://climate-adapt.eea.europa.eu/countries-regions/countries/italy (accessed on 7 July 2017).

49. Friedmann, J. Toward a Non-Euclidian Mode of Planning. J. Am. Plan. Assoc. 1993, 59, 482-485. [CrossRef]

50. Kato, S.; Ahern, J. 'Learning by doing': Adaptive planning as a strategy to address uncertainty in planning. J. Environ. Plan. Manag. 2008, 51, 543-559. [CrossRef]

51. Darchen, S.; Searle Seoul, G. South Korea: Dismantling a highway-Cheonggyecheon Restoration Project. In Global Planning Innovations for Urban Sustainability; Routledge: Abingdon, UK, 2018; pp. 137-150.

52. Crowe, P.R.; Foley, K.; Collier, M.J. Operationalizing urban resilience through a framework for adaptive co-management and design: Five experiments in urban planning practice and policy. Environ. Sci. Policy 2016, 62, 112-119. [CrossRef]

53. Salizzoni, W.E.; Pérez-Campaña, R.; Alcalde-Rodríguez, F.; Talavera-Garcia, R. Local Planning Practice towards Resilience: Insights from the Adaptive Co-Management and Design of a Mediterranean. Sustainability 2020, 12, 2900. [CrossRef]

54. Coaffee, J.; Therrien, M.-C.; Chelleri, L.; Henstra, D.; Aldrich, D.P.; Mitchell, C.L.; Tsenkova, S.; Rigaud, É. Urban resilience implementation: A policy challenge and research agenda for the 21st century. J. Contingencies Crisis Manag. 2018, 26, 403-410. [CrossRef]

55. Ahern, J. Planning for Resilient and Sustainable Cities. In Water Centric Sustainable Communities: Planning, Retrofitting, and Building the Next Urban Environment; John Wiley \& Sons: Hoboken, NJ, USA, 2010; pp. 539-593.

56. Aghazadeh Ardebili, A.E. A Literature Review of the Concepts of Resilience and Sustainability in Group Decision-Making. Sustainability 2020, 12, 2602. [CrossRef]

57. Tira, M. Pianificare la Città Sicura; Edizioni Librerie Dedalo: Roma, Italy, 1997. 
58. Lantada, N.; Irizarry, J.; Barbat, A.H. Seismic hazard and risk scenarios for Barcelona, Spain, using the Risk-UE vulnerability index method. Bull. Earthq. Eng. 2010, 8, 201-229. [CrossRef]

59. Kent, D.; Miller, H.; Waller, G. Scenarios, Real Options and Integrated Risk Management. Long Range Plan. 2003, 36, 93-107.

60. Menoni, S. Pianificare e incertezza. In Elementi per la Valutazione e la Gestione dei Rischi Territoriali; FrancoAngeli: Milano, Italy, 1997.

61. Koks, E.E.; Jongman, B.; Husby, T.G.; Botzen, W.J.W. Combining hazard, exposure and social vulnerability to provide lessons for flood risk management. Environ. Sci. Policy 2015, 47, 42-52. [CrossRef]

62. Kron, W. Flood risk, hazard, exposure, vulnerability. In Water International; Science Press: New York, NY, USA, 2005.

63. Kaźmierczak, A.; Cavan, G. Surface water flooding risk to urban communities: Analysis of vulnerability, hazard and exposure. Landsc. Urban Plan. 2011, 103, 185-197. [CrossRef]

64. Zhou, Q.; Leng, G.; Feng, L. Predictability of state-level flood damage in the conterminous United States: The role of hazard, exposure and vulnerability. Sci. Rep. 2017, 7, 5354. [CrossRef]

65. Pirlone, F.; Spadaro, I. The places and times in risk management. The case of the school system. In Environmental and Territorial Modelling for Planning and Design; Leone, A., Gargiulo, C., Eds.; FedOAPress: Napoli, Italy, 2018; pp. 159-168, (Smart City, Urban Planning for a Sustainable Future. 4); ISBN 978-88-6887-048-5. Available online: http://www.fedoabooks.unina.it (accessed on 20 December 2018). [CrossRef]

66. Pirlone, F. I rischi naturali nelle prassi ordinarie di pianificazione e gestione urbanistica. In L'importanza Della Temporalità Nella Sicurezza del Territorio; Editrice, A., Ed.; Alinea: Firenze, Italy, 2009.

67. Etzkowitz, H.; Leydesdorff, L. The dynamics of innovation: From national systems and "Mode 2" to a triple helix of university-industry-government relations. Res. Policy 2000, 29, 109-123. [CrossRef]

68. Chapman, S.; Sullivan, C.; Palm, C.; Huynh, U.; Diru, W.; Masira, J. Monitoring and evaluation to support adaptive co-management: Lessons learned from the Millennium Villages Project. J. Environ. Manag. 2016, 183, 142-151. [CrossRef]

69. Davidoff, P. Advocacy and Pluralism in Planning. J. Am. Plan. Assoc. 1965, 31, 331-338. [CrossRef]

70. Arnstein, S. A Ladder of Citizen Participation. J. Am. Plan. Assoc. 1969, 35, 216-224. [CrossRef]

71. Forester, J. The Deliberative Practitioner: Encouraging Participatory Planning Processes; MIT Press: Cambridge, MA, USA, 1999.

72. Wagenaar, H. In the Shadow of Hierarchy: Deliberative Democracy and Public Administration. Adm. Theory!Pract. 2002, 24, 231-250.

73. Healey, P. Collaborative Planning: Shaping Places. In Fragmented Societies, 2nd ed.; MacMillan: London, UK, 2006.

74. Enzo, F. Community and plural planning: The open source way to the top of Arnstein's ladder. In Proceedings of the Differences and Connections: Beyond Universal Theories in Planning, Urban, and Heritage Studies. IX YA conference, Palermo, Italy, 23-26 March 2015. [CrossRef]

75. Kammouh, O.; Noori, A.Z.; Taurino, V.; Mahin, S.A.; Cimellaro, G.P. Deterministic and fuzzy-based methods to evaluate community resilience. Earthq. Eng. Eng. Vib. Engl. Vers. 2018, 17, 261-275. [CrossRef]

76. Hjalager, A.M.; Nordin, S. User-driven innovation in tourism-A review of methodologies. J. Qual. Assur. Hosp. Tour. 2011, 12, 289-315. [CrossRef]

77. Yoon, D.K.; Kang, J.E.; Brody, S.D. A measurement of community disaster resilience in Korea. J. Environ. Plan. Manag. 2016, 59, 436-460. [CrossRef]

78. SFei, M.; Zuohang, W.; Qipeng, S.; Kum Fai, Y.; Yanxia, Z.; Huifeng, X.; Shumei, Z. Spatial-Temporal Evolution of Urban Resilience and Its Influencing Factors: Evidence from the Guanzhong Plain Urban Agglomeration. Sustainability 2020, 12, 2593. [CrossRef]

79. Lu, X.; Cheng, Q.; Xu, Z.; Xu, Y.; Sun, C. Real-time city-scale time-history analysis and its application in resilience-oriented earthquake emergency responses. Appl. Sci. 2019, 9, 3497. [CrossRef]

80. Chen, J.; Yang, X.; Yin, S.; Wu, K.; Deng, M.; Wen, X. The vulnerability and simulation of social-ecological systems in a semi-arid area: A case study of Yulin City, China. J. Geogr. Sci. 2018, 28, 152-174. [CrossRef]

81. Lombardy Region POR FESR 2014-2020. Valutazione Ambientale Strategica, Rapporto Ambientale; Regione Lombardia: Milano, Italy, 2014. 
82. Armstrong, M. A Handbook of Human Resource Management Practice, 10th ed.; Kogan Page: London, UK, 2006; ISBN 0-7494-4631-5.

83. Candia, S.; Pirlone, F.; Spadaro, I.; Taramasso, A. Urban resilience and anthropic risks. The case of the Polcevera Valley in Genoa. In Proceedings of the XXIV International Conference “Living and Walking in Cities", Brescia, Italy, 12-13 September 2019.

84. Fabbricatti, K. Resilienza e processi di recupero urbano: Il quartiere "Vasto" di Napoli, in Colucci, A., Cottino, P. (a cura di), "Resilienza tra territorio e comunità: Approcci, strategie, temi e casi", Quaderni dell'osservatorio, n. 21. Fond. Cariplo 2015, 43-48. [CrossRef]

85. Tiboni, M. La prospettiva dello sviluppo sostenibile. Pianificare per la sicurezza la città e il territorio. In Collana Urbanistica Tecnica; Sintesi Editrice: Brescia, Italy, 2002.

86. Fera, G. La Città Antisismica; Gangemi: Roma, Italy, 1991.

87. Municipality of Genoa; Genova Lighthouse City: Genoa, Italy, 2019.

88. IRPI-CNR Hydrogeological Research Institute CNR, Historical Catalog of Geo-Hydrological Events with Damage to the Population in Italy. 2019. Available online: http://polaris.irpi.cnr.it/report/last-report/ (accessed on 1 December 2019).

89. Adaptation: Resilience strategy. The path of the Municipality of Genoa. In The path of the Municipality of Genoa. Urban Agenda for UE; Municipality of Genoa: Genoa, Italy, 2019.

90. Peizer, R. Resilience: A Holistic Approach; Apa Oregon: Portland, OR, USA, 2014.

91. Hynes, W.; Coaffee, J.; Murtonen, M.; Davis, P.; Fiedrich, F. The drive for holistic urban resilience. In Proceedings of the Future Security, Berlin, Germany, 17-19 September 2013; pp. 1-8.

92. Galderisi, A. Città e Terremoti, Metodi e Tecniche per la Mitigazione del Rischio Sismico; Gangemi: Roma, Italy, 2004.

93. Zeng, H.; Talkkari, A.; Peltola, H.; Kellomäki, S. A GIS-based decision support system for risk assessment of wind damage in forest management. Environ. Model. Softw. 2007, 22, 1240-1249. [CrossRef]

94. Xiaodan, W.; Xianghao, Z.; Pan, G. A GIS-based decision support system for regional eco-security assessment and its application on the Tibetan Plateau. J. Environ. Manag. 2010, 91, 1981-1990. [CrossRef] [PubMed]

95. Barbarossa, L.; La Greca, P.; La Rosa, D. Rischi urbani e territoriali. In Rapporto sul Territorio 2018; Inu Edizioni: Rome, Italy, 2018; pp. 41-45.

96. Nino Sulkowska, M.S.; Villa Avendano, A. New Integrated Approach toward Urban Sustainability in Mexican Cities; Inu Edizioni: Rome, Italy, 2017; pp. 324-326.

97. Walloth, C.; Gurr, J.M.; Schmidt, J.A. Understanding Complex Urban Systems: Multidisciplinary Approaches to Modeling; Springer International Publishing: Cham, Switzerland, 2014.

98. Lovelock, J. Healing Gaia-Practical Medicine for the Planet; Harmony Books: New York, NY, USA, 1991.

99. Marshall, A. Unity of Nature, The: Wholeness and Disintegration in Ecology and Science; World Scientific: Singapore, 2002.

100. Cheli, E. Diversità, conflittualità, comunicazione. In Per un Approccio Olistico Alla Risoluzione Costruttiva dei Conflitti, in Benci V., Buccioni I., (cur.); Cultura Della Pace e Gestione dei Conflitti Interpersonali: Roma, Aracne, 2005.

101. Sainz, M.; Gimenez, R.; Hernantes, J.; Labaka, L. Deliverable 2.4: Holistic Resilience Workshop Tecnun; SMR Project: Spain, 2016.

102. RESilience to cope with Climate Change in Urban area Project (2016-2020) European Union's Horizon 2020 Research and Innovation Programme, 2016-2020. Available online: https://cordis.europa.eu/project/id/ 700174/reporting/en (accessed on 1 December 2019).

(C) 2020 by the authors. Licensee MDPI, Basel, Switzerland. This article is an open access article distributed under the terms and conditions of the Creative Commons Attribution (CC BY) license (http://creativecommons.org/licenses/by/4.0/). 